\title{
Forty Years On: Still Searching for the Corporation-Society Paradigm*
}

\author{
JAMES E. POST
}

In 1975, the Journal of Economic Literature published an article by Lee E. Preston entitled "The Corporation and Society: Search for a Paradigm". The article became an important landmark in the evolution of the young, but rapidly growing, field of business and society. This paper reviews Preston's effort to articulate the corporationsociety paradigm. The author, who served as Preston's research assistant when the original paper was written and, later, as his coauthor, discusses Preston's "search for a paradigm", offers an assessment of where the field stands today, and discusses whether, or where, a new paradigm is likely to emerge.

Keywords: Corporate Responsibility, CSR Paradigm, Interpenetrating Social Systems, Social Contract, Stakeholder Theory, Sustainability Paradigm

\section{Vierzig Jahre später: Noch immer auf der Suche nach dem Unter- nehmen-Gesellschaft-Paradigma}

1975 veröffentlichte das Journal of Economic Literature Lee E. Prestons Artikel „The Corporatoin and Society: Search for a Paradigm":In der jungen, aber rasch wachsenden Forschung zu Unternehmen und Gesellschaft ist der Artikel zu einem wichtigen Meilenstein geworden. In diesem Artikel wird Prestons Versuch, das Unternehmen-Gesellschaft-Paradigma zu formulieren, gewürdigt. Dafür wird die „Suche nach einem Paradigma“ diskutiert, eine Einordnung des heutigen Forschungsstandes gegeben, und die Frage erörtert, ob und wo ein neues Paradigma voraussichtlich entsteht. Der Autor hatte Preston beim Schreiben des ursprünglichen Artikels als dessen Assistent unterstütżt und wurde später sein Co-Autor.

Schlagwörter: Unternehmensverantwortung (CSR), CSR-Paradigma, Interpenetrierende Gesellschaftliche Systeme, Stakeholder-Theorie, Nachbaltigkeitsparadigma

\section{Introduction}

\subsection{The Invitation}

The business and society field was in its early history during the 1970s when Lee Preston, a distinguished economist and expert on competition policy, was invited to prepare a survey paper for the prestigious Journal of Economic Literature (JEL). JEL was known to be an authoritative source of information about the important literature in

The manuscript was submitted on 17.05.2015.

Professor Emeritus Dr. James E. Post, Boston University - Questrom School of Business, 595 Commonwealth Avenue, Boston, MA 02215, USA, Tel.: +1-(0)617-353-4162, E-Mail: jepost@bu.edu, Fields of Research: Corporate Social Responsibility, Public Affairs Management, Corporate Governance, Global Codes of Conduct, Business Ethics. 
various subfields of economic science. The editors recognized that the corporationsociety relationship was a topic of emerging importance, and one that was rapidly changing in many industrialized and developing economies. Moreover, the "relationship" involved much more than antitrust policy and competitive practices. Topics such as consumerism, pollution and environmental degradation, workplace discrimination, and other matters of public concern had no obvious "place" within economics, given their non-market features. How, the editors queried, were these activities to be understood within the framework of social science?

\subsection{Formulating the Questions}

Preston described the purpose of the paper as revolving around two central questions: (1) What is the nature of the large corporation? (2) What is the relationship of the large corporation to the economy and to the rest of society? Today, forty years on, these questions still resonate as two of the central questions in the field.

One of Preston's important contributions was the clear specification of the questions and organization of the literature into a coherent framework (or paradigm). Preston's JEL paper signaled the importance of these corporate responsibility questions to economists, business scholars and practitioners in business, government, and other realms of society. By the 1970s, it was clear that narrow economic formulations alone (e.g., role of externalities) were insufficient to capture the multitude of public issues involving the large corporation. The debates of the day required a more robust conceptual language. Preston's article signaled the beginning of such a development among economists and other social scientists (see below).

Lee Preston was an antitrust economist whose work focused on the effects - both positive and negative - of corporation size and competitive conduct on the economy. He began his academic career in 1958 as a professor at the University of California at Berkeley and served as a staff economist on the U.S. President's Council of Economic Advisors and, subsequently, as a member of the White House Task Force on Antitrust Policy. These appointments, plus his research on competition policy, placed him in the front rank of antitrust scholars by the early 1970s.

By that time, OPEC, the international oil cartel, was raising oil prices and flexing its global political muscle. Public and governmental concern escalated throughout the industrialized nations as oil prices rose dramatically. The OPEC action had a destabilizing effect on industrial economies and produced a dangerous world-wide inflation throughout the 1970s.Competition policy and antitrust issues have continued to swirl around key industries as global trade has expanded in recent decades. Forty years later, competitive policy concerns continue to capture public policy attention in recent cases such as European Union's (EU) investigation into Google's market practices, pharmaceutical pricing, and the collusive pricing practices of leading money-center banks.

One truth that has been confirmed time and again is that economic power begets political power. By the early 1970s it was becoming clear to scholars such as Preston that private management and public policy were "interpenetrating social systems" (see Preston/Post 1975), each affecting, and being affected, by the other. These interrela- 
tionships were producing impacts and realities that produced a titanic shift in academic thinking and practical policy making.

\section{Search for a Paradigm}

Preston defined the problem as one of finding (or developing) a framework sufficiently broad and robust to guide researchers in their quest to understand the corporationsociety relationship. According to the Merriam-Webster Online dictionary, a "paradigm" is "a philosophical and theoretical framework of a scientific school or discipline within which theories, laws, and generalizations and the experiments performed in support of them are formulated". The Oxford Dictionary of Philosophy (2010) attributes the term "paradigm" to Thomas Kuhn's The Structure of Scientific Revolutions: a framework of concepts, results, and procedures within which subsequent work is structured. Normal science proceeds within such a framework or paradigm. A paradigm does not impose a rigid or mechanical approach, but can be taken more or less creatively and flexibly (see Kuhn 1962).

Kuhn defines a scientific paradigm as: "universally recognized scientific achievements" (ibid.: 4) that, for a time, provide model problems and solutions for a community of practitioners, including: What is to be observed and scrutinized? What kind of questions are supposed to be asked and probed for answers in relation to this subject? How are these questions to be structured? How should the results of scientific investigations be interpreted? How is an experiment to be conducted? What equipment is available to conduct the experiment?

In The Structure of Scientific Revolutions, Kuhn saw the sciences as going through alternating periods of normal science, when an existing model of reality dominates a protracted period of puzzle-solving, and revolution, when the model of reality itself undergoes sudden drastic change. As we shall see, the characteristics of normal science and Kuhnian revolution apply to the study of the changing corporation-society relationship over the past forty years.

\section{Mapping the Field - Circa 1975}

Preston began his review of the literature by describing the orientation of several early landmark books in the business and society literature. These included Howard Bowen's The Social Responsibilities of the Businessman (1953), Kenneth Boulding's The Organizational Revolution (1953), E.S. Mason, The Corporation in Modern Society, (1959), and Adolf Berle's The 20th Century Capitalist Revolution (1954). It is Bowen, in Preston's view, who most clearly states "the doctrine of social responsibility in terms of the obligations of businessmen to pursue those policies, to make those decisions, and to follow those lines of action that are desirable in terms of the objectives and values of our society" (Preston 1975: 435). It is noteworthy that many of the authors who gave the field its definition were prominent business and government practitioners who saw the large corporation as an economic entity whose social dimensions needed to be explained in the public realm ${ }^{1}$.

1 This phenomenon continues to influence the field during the past forty years as well. 
After reviewing the pro and con arguments stated by various authors, Preston sets the foundation for his assessment of the literature in this way:

"Over the past couple of decades, analyses of the role of the large
corporation in its social context have appeared throughout the litera-
ture, from the farthest reaches of social and political theory to the
most detailed studies of organizational behavior, decision-making,
and management. They are correspondingly disparate in orientation,
methodology, and sophistication. In this varied and widely scattered
literature, there seem to be three main groups, which I will identify as
Institutionals, Organizationals, and Philosophicals" (emphasis added) (Pres-
ton 1975: 436).

According to Preston, the Institutionals generally start from the society end of the corporation-society spectrum, with analyses that are often cast in historical contexts and deal with characteristic institutional types and aggregate sectors - labor unions, consumers, regulatory agencies, formal law, and so forth. The Organizationals, by contrast, begin at the other end of the spectrum, and often with detailed empirical studies of micro-organizations. The Institutionals and Organizationals share, however, the common perspective of both liberal and Marxist social science that the behavior of social units is to be viewed as a 'process of natural history' in which the individual cannot be held responsible for relations whose creature he solely remains.

The Philosophicals, by contrast, begin with some initial conceptions of ideal, or at least improved, conditions with respect to both society in general and the corporation in particular, and then develop arguments in support of their positions or proceed directly to policy prescriptions and implementation techniques. The Philosophicals include, of course, both the severest critics and the strongest advocates of a broader social role and commitment for the large corporation ${ }^{2}$.

Preston notes that a few significant elements of the literature of the day do not fit into his Institutional-Organizational-Philosophical categories. This comprehensiveness is an important characteristic of the Kuhnian paradigm. He notes that the "managerial capitalism" models (see e.g., Marris 1968) seem to fit into traditional economic models and, hence, do not add to the corporation-society literature (see Preston 1975: 436). A second, prominent element in mainstream economics literature that comes close, but does not quite dominate the corporation-society issue is the analysis of social costs, externalities, and so-called "market failures". According to Preston, these "unpriced bads" (e.g., congestion, pollution, racial discrimination) have their theoretical parallel not in the supply of goods and services but in the elusive concept of consumer surplus. Preston found this literature of externalities to be an incomplete framework (ibid.: 437) for examining the corporation-society problem as a whole.

Anticipating what would emerge in succeeding decades as a lively debate in economic theory, Preston named another theoretical problem as the definition of the larger organizational system ("society"), the measurement of social costs, and the shift of private goods to public collectivization or regulations. In his view, the shift of some ac-

2 Preston cites Arrow (1973) as an example of a particularly persuasive presentation of the philosophical case. 
tivities from one institutional or organizational realm to the other may, but may also not, produce important shifts in social costs and changes in the actual conduct of such affairs ${ }^{3}$. These debates would help frame and deepen our understanding of the limits, as well as the scope, of corporate responsibility.

\subsection{Institutionals}

According to Preston, the Insititutionals were "by far, the largest, most varied, and most influential group of contributions and contributors to the corporation-society literature" (Preston 1975: 438). The range of this group covers the historical and legal bases of capitalism and the regulatory institutions and processes characteristic of the "mixed economy". Beginning at the society end of the corporation-society spectrum, the institutional view is anchored in the works of Marx, Weber, Veblen, Commons, and Schumpeter. By contrast, the business-history tradition anchored at the Harvard Business School has long emphasized the connection between the life story of the individual business entities and their social environments, but "rarely in terms of a holistic institutional perspective" (ibid.: 443; see Andrews 1973; Ackerman 1973). ${ }^{4}$ The legalpolitical perspective of such classics as James Willard Hurst (1965) has given rise to extensive legal and regulatory studies, including current research on corporate governance. This stream of literature also gives rise to the analysis of how social pressure produces legal and regulatory change, which, in turn, produces change in corporate behavior as firms adapt to changes in the social and political environment ${ }^{5}$.

Foremost among the Institutionals, in Preston's view, was John Kenneth Galbraith whose diverse books introduced colorful new language to the discussion of the corporation in society - e.g., "The Affluent Society" (1958) and "The New Industrial State" (1967) - introducing the terminology of the "technostructure", "planning system" and "countervailing power", to name but a few. In Preston's view, Galbraith's greatest contribution may have been his incessant emphasis on the need for an "emancipation from belief' in the old models and effort to define a new paradigm of modern nonCommunist socio-economic systems (Preston 1975: 439).

Preston's critique of the institutional literature is extensive, but comes to a close with three key points. First, its focus is on the large corporation as a type of entity within society, and on the relationship between this and other institutional types and the larger social whole (ibid.: 441). It is limited by a selective de-emphasis on some important social institutions that lack a legal-political basis and, hence, treat the corporation as a primary institutional element within an otherwise amorphous and pliant so-

3 In the 1970s and 1980s, for example, policy debates would rage over the responsibility of firms versus government agencies to pay for and administer pollution clean-up programs such as the U.S. "superfund" cleanup of toxic waste sites.

4 Note, this business history perspective underlies much of the organizational literature discussed below.

5 See, for example, two books by prominent practitioners of the day: Ian Wilson, who had an important role at General Electric and defined the corporation's "new social charter" in his book The New Rules of Corporate Conduct (2000) and Marina von Neuman Whitman, whose career included economic forecasting at General Motors and who, in 1999, authored New World, New Rules. 
cial mass. Second, the institutional writers tend to treat the corporation as a single, monolithic body, thereby ignoring its internal diversity. Third, there is an inability to see the problems and the potentials associated with unique innovations and responses on the part of individual social units, corporate or otherwise. By the mid-1970s, the idea of a unitary corporate entity - with a unified corporate behavior - was crumbling as innovative, individualized behavior became more prevalent. This would accelerate throughout the 1980s and 1990s, although it would re-emerge during the 2008 financial crisis as some banks were deemed "too big to fail" and received government bailouts. Moreover, corporate political influence rose as restrictions on the funding of political campaigns were relaxed or removed in 2010 by the U.S. Supreme Court (Citizens United v. FEC).

\subsection{The Organizationals}

The micro-level focus of the Organizational researcher stands in sharp contrast to the macro-level focus of the Institutional researcher. Organizationals begin at the corporation end of the corporation-society relationship. The dominant focus of the Organizationals is the behavior of the firm in response to its social environment. Ackerman (1973) for example, examined how a number of individual firms responded to social demands in several industries. Generally, Preston found that these studies examined the impact of social environment on the firm's responses, rather than how the firm affected the environment. This would begin to change by the mid-1970s (see Bauer/Fenn 1972; Preston/Post 1975; Post 1978; Pfeffer 1978; Thompson 1973).

The focus of this organizational research was on how organizations do in fact behave, not how they are caused to behave by the processes of social change nor how they should behave in the light of some idealized situation or goal. This focus helped produce the scholarly research base that became the bedrock of CSR scholarship during the next several decades.

\subsection{The Philosophicals}

Preston identified a large number of writers whose heavily prescriptive approach emphasized what corporations "ought" and "should" be doing rather than the "is" and "do" of the institutional and organizational writers.

Foremost among the Philosophicals was the fundamentalist position of Milton Friedman, who in 1970 argued that social purposes and the impacts of business organizations are defined entirely by the economic tasks carried out within the system of competitive markets. If such markets provide accurate and sufficient information about all relevant social preferences, then it follows that "the social responsibility of business is to increase its profits" (Friedman 1970).

The opposite view was already well-represented by the 1970s and Preston cites an array of publications by academic and business practitioners who make the case for recognizing that public expectations to specific aspects of business performance have been acknowledged and accepted by various segments of the business community. Preston cites Peter Drucker as an example of a writer who gradually recognizes that 
the social role of the corporation is changing amidst the realities of social impacts and social responsibility (Preston 1975: 445).

Preston also noted three subsidiary themes in the Philosophical literature; each is mentioned because of its considerable growth and impact since the 1970s. One is the specifically religious emphasis set forth in the works of various Catholic writers and evident in the efforts of Pope Francis himself. Anchored in a long tradition of social justice writing, this literature reflects the traditions of religious writers of Catholic and Protestant faiths who have created a public critique of capitalism. The pastoral letters of the American bishops are notable for critiquing the performance and inequality effects of capitalism and market structures.

The second theme, and one of the oldest topics in the entire corporation-society literature, deals with philanthropy. Dating to the early 1900s and Andrew Carnegie's "gospel of wealth", this literature holds that it is the duty of "the man of wealth" to take care of "his poorer brethren (...) doing for them better than they would or could do for themselves" (ibid.: 445). By the early 1970s, the question of how to direct and manage the large and growing volume of philanthropic activity was high on the corporate executive's social performance agenda.

The third topic in the Philosophical literature is the "socially responsible investor" or "Socially Responsible Investment (SRI)". Beginning in the 1970s, writers began arguing that investments of pension funds and university and church endowments could be ranked according to social responsibility categories to favor "responsible" investments and avoid "irresponsible" investments (e.g., companies that sell tobacco products, military weapons, etc.) in order to create a "clean portfolio". The use of social responsibility "screens" and the creation of socially responsible mutual funds have given investors new tools to pressure companies to adopt socially responsible policies. The most notable early example of SRI policy in action was Campaign GM, an 1970s effort to force companies to withdraw from South Africa because of its apartheid policy (see Carroll et. al. 2012).

Each of these three topics would grow in size and importance from the 1980s to the present. The ethics and social justice literature has grown in volume and impact, while philanthropy and socially responsible investment have both become significant fields of research and practice. For example, it is estimated that socially responsible investments now account for more than $\$ 1$ trillion (U.S.) or one in eight investment dollars worldwide (see Lydenberg 2005).

Preston concluded his survey of the corporation-society literature with a number of suggestions about directions in which the field was going and what possible landmarks lay ahead. He made several key points:

1. "(S)erious analysis of the corporation-society relationship requires rigorous and comprehensive conceptions of both the corporation and society, and those conceptions must be articulated in comparable, or at least translatable, terms" (Preston 1975: PP). Referring to the development of various inputoutput models, Preston observed that "society at large might be interested in performance features of the economic system other than the amount of total current output and its distribution" (ibid.: 446). This will lead to the growth in 
social performance and economic performance measurement in succeeding decades.

2. Development of a conception of both the corporation and society requires, in Preston's view, "recognition that both the corporation and society are multipurpose, and hence, their performance is to be explained in terms of combinations of goal-achievements, based on underlying technical possibilities and preferences that are altered over time" (ibid.: 446). This proposition would become one of Preston's long term goals from the 1970s to the 2000s. First, he worked to develop the robust conceptual framework which became the "interpenetrating social systems" model articulated in the celebrated book, Private Management and Public Policy (Preston/Post 2013/1975). This was followed by several decades of research into the quantification and measurement of corporate social performance. Ultimately, this work was synthesized in our book, Redefining the Corporation: Stakeholder Management and Organizational Wealth (Post et al. 2002). In time, this would contribute to the development of double- and triple-bottom-line reporting projects that now report environmental, social, governance and economic performance data. The unified corporate reporting projects of the current day, including the Global Reporting Initiative (GRI) are $21^{\text {st }}$ century extensions of this important line of research.

3. Preston displayed an uncanny sense of this future when he wrote:

"We have only begun to think about performance attributes of the economic system other than GNP and its components; (...) analyses of national priorities and social indicators stress the identification and measurement of multiple, but distinct, goal areas and achievements. At the micro level, new techniques for dealing with discrete variables and combinations thereof may soon permit the construction of $(\ldots)$ models of the multi-purpose firm (...)".

“Then”, he concluded:

"some future J. M. Clark Medalists and Nobel Laureates will simply convert the basic goal structures of both the corporation and society to a single set of comparable concepts and categories; insert the relevant data for technical trade-offs, and preference orderings, and social choice mechanisms; and the new model of corporation-society interaction will be ready to run" (Preston 1975: 447).

Alas, while that day has not yet arrived, the vision remains compelling.

\section{Framing the Field - Circa 2015}

The corporation and society field has grown significantly since the 1970s, but continues to challenge scholars who try to describe the literature in coherent, comprehensive ways.

As the CSR field has evolved, a variety of scholars have written literature reviews attempting to capture the numerous aspects and features of the field (see Margolis/Walsh 2003). In spite of these reviews, the CSR literature remains highly fragment- 
ed. As noted by Waddock, "parallel and sometimes confusing universes exist" (2004: 5). One reason for this fragmentation is the propensity of scholars to study CSR through different disciplinary and conceptual lenses (see Carroll 1999; Garriga/Melé 2004; Waddock 2004). The literature is also quite fragmented regarding levels of analysis.

Dahlsrud (2008) highlighted this definitional confusion in a paper where he examined 37 distinct definitions of the concept of corporate social responsibility. Dahlsrud found a substantial degree of congruence across these definitions, but also a variety of definitional overlaps, contradictions and conflicts. Dahlsrud's solution was to raise the magnification and focus on five overarching dimensions that he found present in each of the 37 definitions: (1) an environmental dimension, (2) a social dimension, (3) an economic dimension, (4) a stakeholder dimension, and (5) a voluntariness dimension (for further discussion see Carroll et. al. 2012: 9-10). This approach provides minimal guidance to future scholars as to the relevant research questions, models, or methods. This conceptual and definitional confusion also underscores one of Preston's virtues: Unlike others, Preston is very precise in the definition he gives to his three literature categories. He then stays close to those definitions, never leading the reader into confused or confusing terminology.

Aguinas and Glavis (2012) argue that CSR is usually studied from one level of analysis at a time, and CSR is primarily studied at the institutional or organizational level compared to the individual (micro) level. Accordingly, they argue, scholars need a multilevel and multidisciplinary review in which the vast and diverse extant literature can be integrated and synthesized in a coherent and comprehensive manner.

This multilevel, multidisciplinary approach is well-illustrated by Aguinas and Glavis' (2012) careful literature review in the Journal of Management. The paper, entitled "What We Know and Don't Know About Corporate Social Responsibility: A Review and Research Agenda", is based on a review of 588 journal articles and 102 books and book chapters. The authors reviewed and synthesized the literature into a multilevel and multidisciplinary framework that presents the literature at what they describe as the institutional, organizational, and individual levels of analysis. ${ }^{6}$

The Aguinas and Glavis framework includes reactive and proactive predictors of CSR actions and policies and the outcomes of such actions and policies, which they classify as primarily affecting internal (i.e., internal outcomes) or external (i.e., external outcomes) stakeholders. The framework includes variables that explain underlying mechanisms (i.e., relationship- and value-based mediator variables) of CSR-outcomes relationships and contingency effects (i.e., people-, place-, price-, and profile-based moderator variables) that explain conditions under which the relationship between CSR and its outcomes change.

The authors reveal a number of important knowledge gaps related to the adoption of different theoretical orientations by researchers studying CSR at different levels of analysis, the need to understand underlying mechanisms linking CSR with outcomes, the need for research at micro levels of analysis (i.e., individuals and teams), and the 
need for methodological approaches that will help address these substantive knowledge gaps. Accordingly, they offer a research agenda based on a multilevel perspective that aims to integrate diverse theoretical frameworks as well as to develop an understanding of underlying mechanisms and micro-foundations of CSR (i.e., foundations based on individual action and interactions).

Unlike Preston, Aguinas and Glavis do not address the truly macro-foundations of the field. In this respect, the discussion of institutional literature is left wanting. Nevertheless, their paper is an important and useful guide to scholars studying CSR at the individual (micro) level and at the individual and organizational levels.

Ironically, Aguinas and Glavis make no reference to Preston's "Search for a Paradigm" paper or to a number of other major pieces in the CSR literature (see Frederick 2006). These omissions point to the proliferation of a literature that has no generally accepted, central conceptual core 7 . Aguinas and Glavis discuss the organizational (firm-level) dimensions found in Preston's framework, but give a different meaning to the institutional dimension that is closer to Scott's (1995) theoretical lens.

There are empirical knowledge gaps as well as conceptual gaps. Surprisingly, the authors do not cite Preston's extensive work on corporate social performance measurement and CSR reporting (Global Reporting Initiative or GRI) or many of the leading pieces of research in the stakeholder management, public affairs, or corporationsociety literature (see Carroll et. al. 2012; Preston/Post 2013/1975; Post et al. 2002). Even a bibliography of 588 articles and 102 books or book chapters is bound to fall well-short of the comprehensiveness the authors seek. The problem is compounded by the fact that the authors also seek to incorporate papers from many diverse streams of research plus more than 20 major journals.

\section{Unresolved Issues: The Paradigm Challenged}

As we look to the future, several core questions challenge scholars and practitioners interested in the relationship between business and society. First, what is the proper definition of the field? Corporation-society? Business and society? Corporate responsibility? Corporate social responsibility? Business ethics? All of these terms have their advocates, and, as Dahlsrud (2008) and Carroll et al. (2012) concluded, there is a centrality around core dimensions of the corporation-society relationship and the definition of corporate responsibility.

Second, what non-market theories, models, and variables must be integrated with the market theories and related factors (e.g., corporate governance) to form a modern theory of the corporation in society?

Third, where do a number of new models and theories such as stakeholder theory (see Freeman 1984) and shared value creation (see Porter/Kramer 2011) fit within the business and society field? What do they explain about the corporation-society relationship?

Dahlsrud (2008) for example, analyzes 37 distinct definitions of corporate social responsibility found in the literature; still, Dahlsrud is not included in the Aguinas and Glavis bibliography. 
Finally, has the nature of the corporation itself begun to change as the creation of social benefits becomes a more prominent feature of established and new organizational entities such as the B-Corporation (see Wilson/Post 2013)?

When Preston wrote in the 1970s, it seemed clear that the large corporation was the economic entity that mattered most to an economy. The large corporation was also an economic entity with considerable political power. Competition policy was a convenient starting point for framing the two core questions that Preston posed: What is the nature of the large corporation? And, what is its relationship to the economy and the rest of society? Today, forty years later, these questions still remain quite central to the corporation-society paradigm.

I do not believe these core questions have been answered satisfactorily, and their discussion is sometimes lost in the underbrush of other issues, questions, policies, and practices. In one of our last research endeavors, Preston, Sachs, and I sought to clarify the most central empirical and conceptual questions in light of the many recent developments in stakeholder theory and management (see Post et al. 2002). We concluded that corporations remain the appropriate unit of analysis in the business-society field and the study of corporate behavior is still the appropriate research focus because "corporations ARE what they DO!" (ibid.: 3, emphasis as in original). Researchers should continue to document corporate behavior, understand what motivates and shapes that behavior, and improve our ability to predict patterns of corporate behavior under varying conditions

In 1975, the free-market paradigm of conventional micro and macro economics was challenged by the emergence of a host of non-market issues (consumerism, environmental pollution, discrimination) that commanded public and governmental attention but which could not be explained in traditional economic terms. Since then, hundreds of scholars have produced thousands of research papers, books, and treatises in an effort to give definition to the business and society field and to answer the questions "To whom, and for what, is the modern corporation responsible?".

Today, forty years later, the business and society paradigm is itself being challenged by a new set of issues that require more systematic analysis and rigorous study. A number of vexing issues challenge corporations (of all sizes) and their executives in the modern context. The pressure of numerous, diverse stakeholders is greater in number and intensity than in the past. The 'texture' of the modern business environment is qualitatively different as news cycles, social media, corporate reputation, and technology all intensify pressures of the change process. In a play on words, it is said today that "You are what you Tweet!".

A number of problems transcend the "normal science" of corporate behavioral analysis and challenge researchers and policy makers alike to think creatively about the responsibility questions. One of the foremost problems in this category is climate change and the challenge of sustainability posed by carbon dioxide emissions into the atmosphere and oceans.

While individual firms can/must adjust behavior to reduce pollution, increase recycling, and develop new solutions to modify greenhouse gas emissions, the collective "public bads" that drive climate change require collective action of a type, and on a 
scale, that seems to be beyond the scope of CSR thinking. Surely the voluntary action of one firm alone, or even that of an entire industry, will not produce a solution, or even a significant impact, on climate change. A "sustainability" paradigm of collective action by business, government, and other social actors on an international scale seems essential, but theoretically and practically elusive. Neither the stakeholder paradigm nor the shared value model seems sufficiently robust to meet the need.

We live in a time, quite unlike the 1970s, when collective action is essential. Free markets seem incapable of providing solutions to problems such as climate change. Global income inequality, population migration, and international disaster relief actions are among a growing set of problems that require new models of transnational cooperation at the organizational, institutional, and personal levels. Writers such as Wayne Visser (2015) and Malcolm McIntosh (2015) have extended their research on business-society issues to the formation of new models of individual and organizational cooperation most of which have yet to be tested on an appropriate scale. And scholars such as Waddock (2015) have documented the efforts of a group of individuals whom she calls "intellectual shamans" - to open scholarly minds to grapple with the so-called "wicked problems" of the age.

Climate change cannot be solved by the free market alone. Sustainability is a concept - perhaps a paradigm - that seems to fall partly within, but partly outside of the business-society paradigm. Because the corporation is not the only contributor to climate change challenges, its behavior cannot eliminate the worst effects of the problem. Moreover, the free market encourages consumerism and creates extremes of poverty and wealth that also transcend individual corporate behavior. At most, we can say that corporate stewardship is a necessary, but insufficient response to the climate challenge.

Climate change, structural income inequality, social entrepreneurship, and social innovation are among the current research topics that do not fit neatly within the prevailing business-society paradigm. Forty years ago it was rarely argued that the global climate would threaten life on the planet Earth; today that is our reality. There was no field of social entrepreneurship or social innovation to generate new models of social and community organization; today, these are the source of hope and optimism.

In 1975, Preston concluded that the multi-purpose corporation would be capable of producing goods, services, profits, and a variety of community benefits. In other words, the large corporation was capable of meeting both the market and non-market demands of a modern society. Today, we find that the large corporation facing intensified competition in global markets, and market positions that are less secure than in the past. Corporate citizenship has now become a matter of strategic "global corporate citizenship" (Crane et. al. 2008). In technology-based industries, however, the threat of excessive market power produces heightened competition and antitrust policy oversight. The rapid growth of new technologies like those provided by Facebook, Twitter and Alibaba disrupt conventional ways of doing business and serving society. The balance between economic performance and social performance is constantly changing, requiring continuous adjustment as both the economic and social agenda change. Preston saw this as pointing toward a future system in which the performance of individual organizations could be measured against the social goals, priorities, and 
macro performance of the economy. We have taken major steps toward that reporting system (e.g., triple bottom-line, GRI, and unified reporting) but remain in search of the paradigm that will guide us toward the future.

In conclusion, forty years ago, Preston recognized that the social contract between business and society is a continuous work in process. It remains one for which there is still no generally accepted paradigm. The work continues from one generation to the next.

\section{References}

Ackerman, R. W. (1973): How Companies Respond to Social Demands, in: Harvard Business Review, July-August, 88-98.

Aguinas, H./A. Glavis (2012): What We Know and Don't Know About Corporate Social Responsibility: A Review and Research Agenda, in: Journal of Management, Vol. 38/No. 4, 932-968.

Andrews, K. (1973): Can the Best Corporations Be Made Moral?, in: Harvard Business Review, May-June, 57-64.

Arrow, K. (1973): Social Responsibility and Economic Efficiency, in: Public Policy, Vol. 21/No. 3, 303-317.

Bawer, R./Fenn, D. (1972): The Corporate Social Audit, New York: Russell Sage Foundation.

Berle, A. (1954): The Twentieth Century Capitalist Revolution, New York: Harcourt, Brace \& World.

Boulding, K. (1953): The Organizational Revolution, New York: Harper and Row.

Bowen, H. R. (1953): Social responsibilities of the businessman, New York: Harper \& Row.

Carroll, A. (1999): Corporate Social Responsibility: Evolution of a Definitional Construct, in: Business and Society, Vol. 38/No. 3, 268-295.

Carroll, A./Lipartito K./Post, J. E./Werhane, P./Goodpaster, K. (2012): Corporate Responsibility: The American Experience, New York: Cambridge University Press.

Crane, A./Matten, D./Moon, J. (2008): Corporations and Citizenship, New York: Cambridge University Press.

Dablsrud, A. (2008): How Corporate Social Responsiblity is Defined: An Analysis of 37 Definitions, in: Corporate Social Responsibility and Environmental Management, Vol.15/No. 1, 1-13.

Frederick, W. C. (2006): Corporation Be Good! The Story of Corporate Social Responsibility, Indianapolis, IN: Dog Ear Publishing.

Freeman, R. E. (1984): Strategic Management: A Stakeholder Approach, Boston, MA: Pitman.

Friedman, M. (1970): The Social Responsibility of Business Is to Increase Profits, New York Times Magazine, September 13, 32-33; 122-124.

Galbraith, J. K. (1967): The New Industrial State, Boston: Houghton-Mifflin.

Garriga, E./Melé, D. (2004): Corporate Social Responsibility Theories: Mapping the Territory, in: Journal of Business Ethics, Vol. 53/No. 2, 51-71.

Kubn, T. (2012/1962): The Structure of Scientific Revolutions, Chicago: University of Chicago Press. 
Lydenberg, S. (2005): Corporations and the Public Interest: Guiding the Invisible Hand, San Francisco, CA: Berrett-Koehler Publishers.

Marris, R. (1968): The Economic Theory of Managerial Capitalism, New York: Basic Books.

Margolis, J. D./Walsh, J. P. (2003): Misery Loves Companies: Rethinking Social Initiatives by Business, in: Administrative Science Quarterly, Vol. 48/No. 2, 268-305.

Mason, E. S. (1959): The Corporation in Modern Society, Cambridge, MA: Harvard University Press.

McIntosh, M. (2015): Business, Capitalism, and Corporate Citizenship, London: Greenleaf Publications, Inc.

Neumann Whitman, M. v. (1999): New World, New Rules, Boston: Harvard Business School Press.

Oxford Dictionary of Philosophy (2010): Paradigm, NY: Oxford University Press.

Pfeffer, J./Slancik, G. (1978): The External Control of Organizations, New York: Harper \& Row.

Porter, M./Kramer, M. (2011): Creating Shared Value, Harvard Business Review, Vol. 89/No. $1 / 2,62-77$.

Post, J. E. (1978): Corporate Behavior and Social Change, Reston, VA: Reston Publishing.

Post, J. E./Preston, L. E./Sachs, S. (2002): Redefining the Corporation: Stakeholder Management and Organizational Wealth, Palo Alto, CA: Stanford University Press.

Preston, L. E./Post J. E. (1975): Private Management and Public Policy: The Principle of Public Responsibility, Englewood Cliffs, NJ: Prentice-Hall.

Preston, L. E. (2013/1975): Private Management and Public Policy: The Principle of Public Responsibility, Palo Alto, CA: Stanford University Press.

Scott, R. W. (1995): Institutions and organizations, Thousand Oaks, CA: Sage.

Thompson, J. (1973): Organizations, New York: McGraw-Hill.

Visser, W. (2015): Sustainable Frontiers, Unlocking Change through Business, Leadership and Innovation, London: Greenleaf Publishing.

Waddock, S. A. (2004): Parallel Universes: Companies, Academics, and the Progress of Corporate Citizenship, in: Business and Society Review, Vol. 109/No. 4, 5-42.

Waddock, S. A. (2015): Intellectual Shamans: Management Academics Making a Difference, New York: Cambridge University Press.

Wilson, F./Post, J. E. (2013): Business Models for People, Planet (\& Profits): Exploring the Phenomena of Social Business, a Market-Based Approach to Social Value Creation, in: Small Business Economics, Vol. 40/No. 3, 715-737.

Wilson, I. (2000): The New Rules of Corporate Conduct: Rewriting the Social Charter, Westport, CT: Greenwood Publishing/Quorum Books. 